\title{
Relationship Marketing in the Industrial Sector for Organic Products: The Assumption of Loyalty Programs Customers and Endomarketing
}

\author{
Graziela Oste Graziano (UNIMEP) \\ graziela.graziano@gmail.com \\ NadiaKassoufPizzinatto (UNIMEP) \\ nkp@nadiamarketing.com.br \\ Yeda Cirera Oswaldo (UNIMEP) \\ yoswaldo@unimep.br
}

\author{
Antonio Carlos Giuliani (UNIMEP) \\ cgiuliani@unimep.br \\ Valéria Rueda Elias Spers (UNIMEP) \\ vrueda@unimep.br
}

Dagmar Silva Pinto de Castro (UNIMEP)

dscastro@unimep.br

\section{Dalila Alves Correa (UNIMEP)}

dacorrea@unimep.br

\begin{abstract}
The aim of this study was to analyze the profile of the focus of Relationship Marketing materialized in loyalty programs and Endomarketing, adopted in a specific branch of the agribusiness sector, the organic products. Methodologically, we started with an exploratory study as a first step in the theoretical framework and identification of 24 companies producing organic food raised in the survey by observation in supermarket chains. In a second step, a Descriptive Study non-probabilistic sample of convenience of 50\% of the universe, 12 companies were investigated through interviews with people with experience, namely, the executives linked to Internal Marketing and Loyalty Programs. The results indicate a higher incidence in the use of loyalty programs compared with programs endomarketing industries surveyed, as well as identifies the profile of the shares of each program
\end{abstract}

Keywords: Relationship Marketing, Agribusiness, Loyalty, Endomarketing.

\section{INTRODUCTION}

The marketing concept has evolved from a virtually operational view, that defined marketing as "an applied economics arm to distribution channels studies in shortages seasons, time of guidance for production, in which everything was produced was eagerly respondent "(NEVES, 2008, p.18), for a focus on relationship and customer focus.

This evolution of marketing is a result of changes in the competitive landscape, synthesized by Gonçalves (2003 p.1), as "fierce competition, more demanding customers, increasing the total quality combined with low cost, widely available information about competitors and technological change very intense ".

Similarly, with the increasing level of competition and new forms of communication, where more offers are made at the same consumers every day, has changed profoundly customer behavior. On the one hand, consumers are more savvy, another is seduced every moment by another product or brand. As quality became a constant item of most products, the focus of competition for conquest and customer loyalty migrated to the relationship.

However, Relationship Marketing, to be implemented from a perspective of Customer Focus, uses the broader concept of customers (WHITELEY, 1996; Gummesson, 2010), which includes all organizational stakeholders: internal customers (employees), the intermediaries (distributors, suppliers, for example) and end (users and potential consumers). The Relationship Marketing as philosophy, seeks to improve the competitiveness of the company by the external customer loyalty, commitment by the internal client with the organization's marketing goals and the commitment of the intermediary client with quality, deadlines and specifications defined by the market. 
Customer focus, according to Ribeiro and Cobra (2000), is the effort to identify customer needs intangible, ie the perceived value behind the face value. Requires constant research of customer needs and expectations, whether in pre-sale, sale, or post sale.

Thus the Relationship Marketing aims to deploy long-term customer relationships in all the aforementioned categories, from the identification of focused programs and services in their expectations and that add value to the sale of a product.

This work focused on the construction of such relationships from two points of view: when turned to the foreign customer, generating customer loyalty programs and targeted to internal customers, generating Endomarketing programs.

The Internal Marketing "takes care of the relationship between the company and its employees. This means that employees are now treated as internal customers "(Limongi-FRANCE, 2009, p.149).

The process of Relationship Marketing, when the focus is the internal customer, requires the search for the best cost / benefit and investment in motivated and trained to serve customers.

The prioritization of human skills by organizations, is the recognition that the human capital of the organization is a decisive factor in a competitive environment. To obtain the commitment of employees to the satisfaction of the external client, it is necessary to have motivated people in the organization, feeling important to the company and, consequently, with positive performance, then, is the human assets of the organization living with the business day to day annoyances (CORREA; GRAZIANO; GRAZIANO, 2006).

But when facing the external customer, the Relationship Marketing can start with the right choice of the segment, identifying their needs, defining the provided and additional services to add value before the expectation of customers, aiming at generating programs competent Loyalty.

Academically, the subject of this study is tied to what Brodie, Coviello Winklhofer (2008) called Relational Marketing, based on strategies related to the effort to build relationships on a dichotomous approach to transactional marketing (TM), or transactional marketing, supported by marketing mix strategy. Vavra (1993) explains that the purpose of Relationship Marketing is not the realization of an independent sale, but rather the development of a series of transactions before the actual sale and after-sales period.

The study aimed to investigate the profile of use in agribusiness, two relationship marketing tools, such as: the internal marketing programs (aimed at the internal audience, employees) and Loyalty Programmes (aimed at end consumers), materializing assumption of Focus Strategy in the Customer Relationship Marketing. Set out the following objectives: a) to raise the production of organic industrial companies in the market; b) To investigate the existence of loyalty programs for customers; c) investigate the existence of Internal Marketing Programs; d) to analyze the profile of each Endomarketing program (PEnd): Applicability of time, offered and achieved benefits, scope of the involved levels, types of tools used: training, internal communication, research, selection, motivation, training and career path; e) to analyze the profile of each customer loyalty program: duration of time, benefits offered, affected segments, types of tools used: communication, market research, customer service after sales, customer service service (SAC) and CRM; f) to compare the incidence of each type of program priorities in the industries of agribusiness eg organic products) to compare the profile of the assumption of Relationship Marketing by industries of organic products through Fidelity Program and Endomarketing.

This work investigated the application of the theory of relationship marketing when focused on the aspect of external customer, creating loyalty programs for customers, and when focused on internal customers, generating Endomarketing programs in the segment of organic products from the agribusiness sector, specifically link the producers of processed organic foods. The production and marketing of organic products is a marketing system that includes everything from the farmer to the manufacturer of organic processed foods, processors, wholesalers, distributors and retailers, to reach a special public who have concerns with the intake of healthy products. Methodologically the work were part of an exploratory and descriptive study with twelve representing industries managers of $50 \%$ of the universe of industrial agribusiness organizations that offer organic products in the country. 


\section{Do Transactional MARKeting (MT) to Relationship MARKETING (MR)}

The marketing approach has been changing: from mass marketing to segments, reaching called Relationship Marketing (RM), focused on building lasting customer relationships, hence the term "customer focus" Strategies for identification MR.

The concept of relationship marketing has emerged in the fields of marketing services and industrial marketing (Jackson, 1985). It was from 1979, according to Dwyer, Schurr and Oh (1987) who were the first comments on the Relationship Marketing, in which trade were results of relations between company and customers on a long-term perspective. Albeit in a simplified manner, the concept of Relationship Marketing has existed since the trade began to take place in an organized manner, complement and Parvatiyar Sheth (1995). But the new marketing approach only began to attract the attention of researchers from the 1980s (YAMASHITA and GOUVÊA, 2004), appearing more prominently in the next decade, especially as an approach to meet the increased competition.

Considered by Tofoli, Tofoli and Santos (2006), one of the key concepts arising in marketing in recent times, the Relationship Marketing, preaching the creation of partnership ties between businesses and customers, was born mainly because companies realized that the cost of communication and sales (advertising in mass media and keep sellers covering their tracks) before represented by routine tasks and low cost, were becoming too costly.

There are, however, divergent views on the origin of the term. Cobra (2009) assigns the Gummeson (2010); already Brodie et al. (2008) reported Thomas (1976), while associating the word Berry (1983). But this new approach is a result of changes in environmental competitive landscape, as explained McKenna (1996, p.46), "a world where consumers have so many choices, they may be unstable. This means that modern marketing is a battle for customer loyalty. "

In the words of Tofoli, Tofoli and Santos (2006), the constant changes taking place in the business world, make enterprises become more competitive, leaving to the consumer many options products, services, brands, quality and suppliers. The authors recommend that companies provide superior value to its customers to be successful. In this perspective, would a philosophy focused on the product and transaction other focused on the customer and the market, which implies that the company listen to the market by checking their demand to shape up this new market definition.

To this end, Kotler; Armstrong (. 1998, p 397), say: "the best way to keep customers is to offer you high levels of satisfaction and value."

In the process, Tofoli, Tofoli; Santos (2006) warn that companies pass the focused marketing in the transaction, the Transactional Marketing (MT), as called Brodie et al. (2008) for Relationship Marketing (RM), customer focused and aims to develop loyalty programs.

Even in the 1980s, Berry (1983) used the term as part of a critique of service marketing literature, arguing that entrepreneurs have focused too much on attracting consumers for products and services. The author defends the change in the transactional approach, in which marketing efforts are focused on attracting customers to a relational approach, where attracting new customers should be seen only as an intermediate step in the marketing process. Thus, the relational approach has the main goal to keep customers.

The Relationship Marketing (MR) challenged the Transactional Marketing in theory and in practice. The origins of Transactional Marketing were in microeconomics before the Second World War, when economists developed the price theory to encompass what they called oligopolistic competition (Waterschoot; VAN DEN, 1992).

This theoretical development, according Mc Garry (1950), led to a series of marketing variables lists deducted from profit equations. Borden (1964) introduced the concept of the marketing mix, a list of 13 variables (product, price, brand, distribution, personal selling, advertising, promotions, packaging, display, handling, physical maintenance, investigation and analysis), traders would have to consider, in any organizational situation. McCarthy (1960) presented a mix management marketing strategy, replacing the original proposal for Borden (1964) of 13 variables into the frame of the 4 Ps (price, product, promotion and place). 
Economic conditions also conspired in O'Malley's vision; Patterson (1998) to reinforce the superiority of the marketing mix due to the need of high consumer confidence, little development of distribution channels and fierce competition. The marketing mix became the basis of Transactional Marketing, the authors Takala and Usitalo (1996).

Thus, the Transactional Marketing to Gonroos (1991) maintains the assumption of microeconomic their origins in the marketing mix is used to help optimize the company in its profit function. As a result, in the opinion of Bitner et al. (1994), companies considered that the marketing objectives have been met on the client attraction point - that is, in exchange for time. The author reports further that there was a growing recognition that, in marketing a service or product, the goal should be not only attract, but then keep and maintain the customer, to develop a long-term relationship with them.

Brodie et al. (2008) state that marketing strategies are essential to any company that aims to success, because, together with the creation of value, can become the great advantage for success in the current environment, increasingly competitive and less predictable.

Concern for the customer and their satisfaction has vital role for the organization, in order to prevent migration to the competition. But the Relationship Marketing is not simply send direct mail, phone calls, electronic mail, flyers or brochures to customers, as warn Olbrzymek, Olbrzymek; Bretzke (2005): is to study existing customers and to distinguish who can be considered only customer, partner and lucrative, to then be able to work loyalty. It is also spending the time necessary to serve you and to anticipate their needs; enchant you so that you do not want to leave the status of being important and unique.

The Relationship Marketing "is essential to the development of leadership in the market, the rapid acceptance of new products and services and the achievement of customer loyalty" (MCKENNA, 1992, p. 105).

\section{Internal Marketing: The Internal Public Programs}

To Limongi-France (2009), one of the main concerns of the administrator is to find new ways to promote motivation and satisfaction in the workplace, in order to integrate workers to organizational goals. Halal (2000) stresses the importance of taking care of employees exactly how to do with external customers - in order to keep the business running, as people are fully responsible for the future of organizations. The economic value of the employee's knowledge surpassed all financial assets, capital, investments, patents and other resources of most companies. Thus, organizations need to really know how to use your most valuable asset: knowledge and creativity that resides in the minds of its employees. According to Souza and Santos (1992), a strategy that has been applied for this purpose is the use of marketing with the workforce of the organization. Such a strategy, in implementing it, is materialized in Internal Marketing Programs.

The term Endomarketing, according to Brum (2010), was recorded in Brazil in 1996 by Bekin (1995) as a result of his experience in the melee of his professional activity, then the middle management of a multinational company, which had some problems such as: low integration between departments and divergent views on the functions. Faced with these problems, he concluded that people did not know in depth the company they worked for and this situation was a challenge whose solution was not in books. It was necessary a tool to tune the employees, promoting a reorientation of goals, along with an internal reorganization of the company. So the Endomarketing can facilitate exchanges, captivating and cultivating certain harmony to strengthen interpersonal relationships and, above all, internal communication.

The Internal Marketing activities for Camel and Vidal (2006), should not be focused only on the incremental improvement through one-off and sporadic actions, but rather to create an individual growth environment, which fosters the collective performance in the pursuit of organizational learning continuous.

The prefix endo means "inside, within", showing the idea of internalization, ie something moving inside. In this case, the Endomarketing should be understood as the marketing is carried out within organizations, argues Limongi-France (2009).

According to CerqueiraNeto (1994, p. 49), "the Endomarketing means facing marketing into the company, ie it consists of a set of actions and integrated means of communication for employees to have and know of its importance for success ". 


\section{Consumer Loyalty}

The Loyalty Program for Rocha (1999) emerged as one of the tools of Relationship Marketing, and aim to show customers eye the advantages that the organization can offer in order to achieve increased involvement with the company.

Rocha et al. (2006) establish the difference between the Loyalty Programmes and Sales Promotions. The loyalty programs originated in airlines, in the $80 \mathrm{~s}$, as a way to give back customer preference, and soon spread to Sector Service Delivery and Financial. The Loyalty Programmes aim to establish a bond that resists time and bring results in the medium and long term. Already sales promotions aimed at remedying a problem or create a sales volume at any given time, working primarily in the short term.

For a loyalty program succeeds, it takes some requirements under Building (1998):

- the offered product must have sufficient contribution margin;

- those offered rewards should be linked to the perception of high value;

- the sponsoring company should have a long-term commitment;

- the program should be simple.

Johnson and Leger (. 1999, p 36) state that to obtain positive returns with loyalty strategies, the organization should seek to develop four actions:

- select suitable customers: it's time to set the target audience loyalty strategy, ie the most profitable public to the company, and understand the variables valued by this audience;

- deliver additional value: use the information based on variables valued by the public and provide access in different ways in order to attract their participation;

- foster continually the relationship: seek regular contact with customers through offers and appropriate communications;

- go the right way: is to assess and make adjustments in the actions carried out so that the result is enhanced.

\section{Organic Products: Sector in Study}

The concept of agribusiness, as presented, is also assumed by organizations such as Embrapa (2011), including the sum of production and distribution of agricultural supplies operations, production operations on the farms, storage, processing and distribution of agricultural products, and items produced from them.

Indeed, the modern diet has led not only to a disaster on human health, but also to a number of environmental problems. The search for quality food is becoming a major concern for conscious consumers, argues Darolt (2002). As a result of some studies, Berlin, Lockeretz and Bell (2009) concluded that the most sought after attributes by consumers aware when purchasing products: taste, nutritional value, freshness and trust in the seller.

Thus, organic, foods increasingly sought after by some consumers in supermarkets are defined by Brazilian law as products of an agricultural production system in which techniques are adopted that optimize the use of natural and socioeconomic resources available, while respecting the cultural integrity of rural communities.

Given the growing environmental degradation, which includes the entire ecosystem, and studies on the dangers to human health due to the consumption of food contaminated with chemicals, there is the alternative of a supply with higher quality, represented by organic products which have gained many consumers, so that these foods are increasingly popular in supermarkets. This demand for organics, the design Hoff (2005), is derived from the need to reduce the quantity of chemical substances ingested as an important step in improving the quality of life, considering the accumulation of aggressive agents that mankind has to adding their day-to-day (stress, pollution). 
To Lages (2003), environmental concern has assumed an increasingly important role for companies and for society as a whole, not only by growing demand from governments through specific legislation and standards, but also by market pressures, arising mainly from the consumer, which shows more informed, demanding and seeking better quality of life.

Based on the above, it can be justified, then the pursuit of sustainable development or sustainability, which involves economic, social and environmental development. The methods used in organic farming aim to maintain stable and self-sustaining ecosystems through ecological principles and conservation of natural resources.

\section{Methodology}

The study was conducted in two stages: first, the exploratory aimed to clarify the concepts linked to the theoretical theme of reference. The exploratory study relies on several sources of information, the first of which secondary data. The research on secondary data initially involved books, magazines, theses and dissertations on the subject, research in scientific events, theses database of the University of São Paulo-USP and other Masters and PhD programs, documents of the organizations under study such as catalogs, reports and other.

Such research activities are the preliminary investigations of the project; Also at this stage, was carried out research by observation, another source of information for Exploratory Studies, according to Mattar (1996): We performed a survey of the manufacturing industry, in the sections of organic products supermarket chains (Carrefour, probes and Sugar Loaf), via research on product packaging offered there: they were identified 24 industries that would become the universe of Descriptive Study conducted in the second stage of the research.

Still in an exploratory level, research on secondary data in a second step included consultations the search of electronic media on the web, in order to investigate, on the site of producing organic products industries, reference to oriented Relationship Marketing Strategies to their public: internal (Internal Marketing Strategies) and external (Strategies Loyalty .. This technique, according to Severino (1999), is a valid source of information.

In the second stage of the research was conducted Descriptive Study, another source of information were people with experience - the leaders and people related to the management of Internal Marketing Programs and Customer Loyalty.

Two questionnaires were used with the managers of a sample twelve manufacturers of organic products among the 24 investigated and contacted organizations; so the research sample was not probabilistic for convenience, according to Mattar (1996).

The first questionnaire aimed to analyze the profile of each Endomarketing program and the second in order to collect data for analysis of each Customer Loyalty Program.

The main points investigated in the questionnaire Endomarketing programs concerned the identification (or equity securities of the offered programs), objectives, people involved. For evaluation of actions and benefits of such programs aimed at the internal audience, analytical categories were created from the literature. Since the questionnaire targeted to loyalty programs, questioned managers about the profile of prioritized segments and the actions that were part of such programs, and the latter were also defined from the bibliographic references. Finally, also based on the literature, we investigated the instruments used in customer relationship management: market research, CRM use (in the questionnaire, identified as "computerized system"), communication, customer service and after-sales SAC (Customer Service).

The data collected from the companies were characterized by a descriptive analysis of the data collected in the sample, presented in tables and graphs through the analysis of which seeks to meet the objectives of the study. Secondly, the information collected in the survey were analyzed qualitatively through analysis and interpretation of results.

\section{Results Fidelity Program}

In this section we present the results derived from the tabulation, analysis and interpretation of data investigated in relation to loyalty programs of 12 organizations surveyed.

Table 1 show that all the investigated companies develop loyalty programs for their customers. 
Relationship Marketing in the Industrial Sector for Organic Products: The Assumption of Loyalty Programs Customers and Endomarketing

Table1. Companies that possess Loyalty Programs

\begin{tabular}{|l|l|l|}
\hline PossessConsumerLoyalty & F & \% \\
\hline Yes & 12 & 100 \\
\hline No & 0 & 0 \\
\hline Total & 12 & 100 \\
\hline
\end{tabular}

Source: elaborated by the authors

Note: The percentage analysis was calculated based on the number of companies investigated, ie 12 companies.

Table 2 details the types of loyalty programs developed by organic products industries. Can be seen based on the information in Table 16 that $75 \%$ of companies invest in Customer Care Service (SAC) as a way to build customer loyalty, 33\% for customer loyalty disclose revenues on their own sites, $25 \%$ more merchandising of products and $17 \%$ provide health professionals to provide services to the consumer.

Regarding the lifetime of Fidelity Program is noticed that in every company programs are one year or more of operation. Such information is detailed in Table 3.

Table2. Types of Customer Loyalty Programs offered by Organic Products Industries

\begin{tabular}{|l|l|l|}
\hline Tipos de Programas de Fidelização & F & \% \\
\hline InstructionGuidesConsumer & 1 & 8 \\
\hline Health Professionals & 2 & 17 \\
\hline merchandising & 3 & 25 \\
\hline Service Customer Service (SAC) & 9 & 75 \\
\hline Blogs & 1 & 8 \\
\hline RevenueDisclosure & 4 & 33 \\
\hline Online Store & 1 & 8 \\
\hline Chat: Chat & 1 & 8 \\
\hline Training for Producers & 1 & 8 \\
\hline ISO 9000 & 1 & 8 \\
\hline Informationonnutrition & 1 & 8 \\
\hline gifts & 1 & 8 \\
\hline Attracting new customers & 1 & 8 \\
\hline
\end{tabular}

Source: elaborated by the authors

Note: The percentage analysis was calculated based on the number of companies investigated, 12 companies.

Table3. Effective Time Loyalty Programs

\begin{tabular}{|l|l|l|}
\hline Tempo de Vigência do Programas de Fidelização & F & \% \\
\hline 1 year & 1 & 8 \\
\hline One year and five months & 1 & 8 \\
\hline 2 years & 1 & 8 \\
\hline 7 years & 1 & 8 \\
\hline 11 years & 2 & 17 \\
\hline 15 years & 1 & 8 \\
\hline 16 years & 1 & 8 \\
\hline over 5 years & 1 & 8 \\
\hline notanswered & 3 & 25 \\
\hline Total & $\mathbf{1 2}$ & $\mathbf{1 0 0}$ \\
\hline
\end{tabular}

Source: elaborated by the authors

The objectives of loyalty programs were highlighted, which are: Search customer satisfaction; Repair of complaints; Send samples for tasting at points of sale; Deliver the agreed deadline; Deliver new products and consumption habits; Give produced organic products separately in the conventional production; Looking to nature as its ally, respecting your time, soil limitations, water and climate, showing the inter-relationship that exist between all the elements that make up the environment, produce economically, but following and respecting the rhythm of nature and seek balance with nature; Promote periodic visits of an inspector at the production site, review inspection report by farmers, processors, academics, technical and consumer representatives, make residual analysis to check the purity level of the product and approval of the farm, within the standards of organic quality; 
Inform the form and method of preparation; Perform product exchanges; Improve customer service and communication with the client; promoting information for a better quality of life;

Add value and increase the confidence level of the product line; Collect packaging, send for recycling and redeem for gifts to consumers of products; Visiting customers and open new markets; Build customer loyalty as organic product consumer; and Attend trade shows.

It can be seen that the segment prioritized by organic producers in loyalty programs is the category 4 , with $92 \%$ of the votes, being appointed by 11 companies of the 12 companies surveyed. Grade 4 corresponds to the regular customers who buy the company normally, whose confidence has been achieved Category 5, representing the defenders customers, meaning those customers who are always on the side of the company, they consider the company's business as a reference and have other wonders about the organization, was the customer segment prioritized by loyalty programs by nine companies, representing $75 \%$ of the votes. Among the companies surveyed, 67\%, that is, eight companies indicated that customers prioritize Category 2, that is, those buyers who are satisfied with the initial experience and start to do business with the company, but not effectively. Half of the investigated companies, seeks to prioritize loyalty programs experimenters customers, represented by people who take knowledge of the company and its offerings through first experimental purchases. Of the 12 companies, four (33\%) invest in any customers who have been conquered, but still maintain alternative sources for businesses making the organization. Only one company priority in their loyalty programs category 6 , ie, the selected clients on the other (s) criteria (s) adopted (s) which were not specified.

It is noticed that $92 \%$ of companies, ie 11 of them, through customer loyalty programs, create a permanent relationship between customer and company (Category 1), while $58 \%$ of companies direct the actions of loyalty programs to increase the sales volume in specific situations (category 2). Half of the investigated companies, ie 50\% search on the actions of loyalty programs serve more frequent consumers with increased spending and more faithful (category 3), and these ongoing actions and long-term (category 7). In four of the investigated companies, ie 33\%, the loyalty programs meet any buyer, independent of your profile (category 4). For $17 \%$ of companies, the actions of the programs offer reward to the customer in the short term (category 6) and planned for a specified period (Grade 8). Only one company has the action of loyalty programs offer rewards to the customer in the long run (category 5).

The answers are presented in descending order of agreement, that is, first it appears the reference to "strongly agree" to "strongly disagree". Eight companies indicated that they strongly agree with the statement that loyalty programs have leadership support. Through these programs, companies seek a long-term commitment to customers with positive impacts. Organizations providing constant communication with customers in order to keep up with their needs and the possible changes that can help to build consistent targets aiming to increase the perceived value of their products to their customers. Seven companies fully agree that loyalty programs are perceived as a competitive advantage and include employee training and internal communication. Six companies fully agree that loyalty programs include marketing strategies focused on consumer, contribute to a positive relationship between customer satisfaction level and loyalty toward the company. These organizations seek to better understand the customer that their competitors and try to maintain interaction with customers through ongoing dialogue. Five of the companies surveyed strongly agree with the statement that loyalty programs are the responsibility of a responsible manager. Supported by a technological infrastructure, enable efficient Customer Relationship Management. Such organizations seek frequent contact with customers through offers and appropriate communications. They said that customers linked to loyalty programs are less sensitive to the quality and price competition. Four companies indicated the development of assessments and promoting adjustments in the actions, through loyalty programs.

For six of the surveyed companies, loyalty programs contribute to the continuous search for innovations in the way they conduct business. Five organizations partially agree with the statement that the rewards offered by loyalty programs are associated with the perception of the factors that add value to the product, from the viewpoint of customers and programs provide services through the contact tools with the consumer. Four - or $25 \%$ of the sampled companies only partially agree with the statement that loyalty programs involve employees in action. Only four organizations agree that in loyalty programs is provided methods for measurement and disclosure of financial results of loyalty 
programs and, finally, six (half of the companies surveyed) disagree with the statement that loyalty programs only include products more high contribution margins.

You can indicate that of the 12 companies investigated, nine or $(75 \%)$ use the media as instruments of Customer Relationship Management. For seven organizations and 58\% indicated using the Customer Care Service as a tool for customer relations. Five companies (42\%) use market research to foster relationships with customers. Three firms $(25 \%)$ invest in after-sales service and other instruments not displayed. Only two companies (17\%) of the surveyed segment used as a tool for relationship management with customers the computerized system.

\section{Results of Internal Marketing Programs}

In this topic, are presented the results derived from the tabulation, analysis and interpretation of data investigated in relation to Internal Marketing Programs of the 12 organizations surveyed.

Note that $42 \%$ of the investigated companies are middle class company with a staff of 100 to 499 . Of the companies studied, $33 \%$ of are the small category, with a staff of 20 to 99 employees. Finally, $17 \%$ of companies are included in the category of micro company with up to 19 employees.

It is noticed that the investigated companies ten said they have Endomarketing programs, representing $83 \%$ of the sample.

Note, too, that companies that invest in Endomarketing programs already developed for over a year. The maximum duration of time between 3 months to 11 years. As for the employees involved in the programs, the information indicated the involvement of all employees of organizations that promoted Endomarketing programs. Types of Internal Marketing programs in which companies invest are: Quality of Life; Training training people; Merchandising Products employees; Bulletin board; Internal Journal; Organizational culture; Manuals; Pamphlets; Organizational Behavior; Organizational Change and Organizational Climate

The objectives of the Internal Marketing Programs and some of his instruments are listed below:

- promote awareness and practice of attitudes that promote well-being (through nutrition education activities on leisure, physical activities, on how to handle stress and other problems);

- promote awareness of the care for the environment (activities on sustainability);

- seek the commitment of employees; prevent potential problems with products;

- keep well-informed employees;

- introduce new products for employees, to favor the sales process; Distribute samples internally in product launches;

- inform employees about organizational issues;

- introduce the company;

- recognize the cultural diversity;

- integrate the employee with the communication of internal and external information relevant;

- retain employees;

- to train, develop and recycle the employees;

- maintain a healthy environment in the company;

- encourage the initiative and maintain motivation;

- prepare flyers to inform and integrate the employees in the organization's policies;

- to develop actions in benefit of customers; 
- provide motivation, appreciation and recognition of employees;

- to improve productivity levels;

- reduce costs;

- improve the quality indices;

- promoting education and development of employees;

- develop flexibility in the workplace;

- avoid the gap between the areas of the company;

- review the strategies of the company;

- to present the results achieved on a monthly basis for the whole team; and

- make organizational climate survey and necessary corrections.

As for the actions and benefits, five companies (42\% of the sample companies) said they strongly agree with the statements of the Internal Marketing programs encourage the participation of all employees of the organization, improve attitudes and behaviors in relation to their occupations, create and promote innovative ideas in organizations dedicated to good customer service. Four companies (25\%) strongly agree that loyalty programs using research to identify the needs and desires of employees, include benefits to meet the expectations of employees, attract, develop and retain talent, ensure that all employees have the necessary information to act on the client's benefit. Seek to maintain a working environment that provides motivation, appreciation and recognition of people, using internal communication channels in order to achieve improvement in relationships, regardless of hierarchical level and work training from the perspective of education and development. Three of industry leaders $(25 \%)$ strongly agree with the statements that Internal Marketing programs encourage all employees in the adoption of the mission, vision, objectives, strategies and business tactics. Seven companies (58\%) partially agree that Endomarketing programs contribute to improving productivity. Five firms (41\%) partially agreed with the statement that Endomarketing programs improved the attitudes and behaviors of employees in relation to employment. Four representatives of organizations (33\%) partially agree that Endomarketing programs come from research to identify the needs and desires of employees, ensuring that all employees have the necessary information to act for the benefit of customers. Respondents said these companies have created environments and situations that motivate their employees, thus contributing to the improvement of quality levels and to overcome internal resistance to the changes. Three companies (25\% of the sample companies) partially agreed with the statement that the Internal Marketing Programs stimulate the adoption in all the mission, vision, objectives, strategies and business tactics.

Five of the organizations (41\%) agree that the only Endomarketing programs include career plans as motivation tools and favor the recruitment and selection. For four $(33 \%)$ of the surveyed firms, the Internal Marketing Programs help reduce costs. Finally, for three of the companies in the sample the Endomarketing programs do not reach employees in completely operational, intermediate or management.

\section{CONClusion}

By identifying the existence of Relationship Marketing programs developed by industries in this segment for the workforce, it was evident that most companies have Endomarketing programs (10 companies of the 12 companies surveyed), and the types of programs offered attached to items like : organizational culture, behavior change and organizational climate, billboard, manuals, newspaper and pamphlets, quality of life, training and merchandising products.

About the time of effectiveness of the Internal Marketing Programs, there is variation from the 3 months to those who have tem11 years of implementation.

The objectives of the Internal Marketing programs are aimed at promoting the well-being, commitment search and training, and inform employees.

The greatest benefits offered by the Internal Marketing Programs, pointed out by the companies are: stimulate the participation of all employees of the organization; improve the attitudes and behaviors of employees with respect to employment; create and promote ideas in organizations dedicated to good 
customer service; contribute to the improvement of productivity rates; favor the recruitment and selection; and include career plans as motivation instruments.

Regarding the aspect of coverage of Endomarketing programs, it was detected that is total, that is, the information indicated the involvement of all employees of the organizations consulted.

Analyzing another study shed: the Loyalty Programmes, it was recorded the presence of time varying from 1 to 16 years. Comparing the results from the assumption of Internal Marketing programs with Loyalty, it is clear that entrepreneurs, first, took the focus on the external customer with Loyalty programs (longer duration, 16 years), and then the Endomarketing (11 years).

The types of loyalty programs offered by more organic products industries are the Customer Care Service (SAC), disclose revenues, merchandising and healthcare professional guidelines.

It can be put that loyalty programs of organic industries aims to: customer satisfaction; bugfix; sending samples; dissemination of new products; on-time deliveries; information on the use of materials; improving customer service, communication and trust with the client; and promote the exchange of products for gifts.

The prioritized customer segment are the regular customers, ie those who buy the company for some time. The Loyalty Programmes provide constant communication with customers to understand their needs and help build consistent targets in order to process the products and services in value; They have leadership support; seeking constant innovations in the way of doing business and there are methods provided for measurement and disclosure of financial results of such programs.

The instruments used by companies in Relationship Management Customers are the media, among which can be cited: phone, magazines, pamphlets, newspapers and internet.

It can be seen on the above that there is a higher incidence in the industries to invest in loyalty programs, for all investigated companies have some kind of action aimed at the foreign customer. Have internal marketing programs, of the 12 companies, 10 develop some targeted action to the internal client. This result shows the inverse in relation to the authors Kotler and Armstrong (2007), highlight: the internal marketing must precede external marketing.

This study is the assumption of Relationship Marketing in 50\% of the contacted companies, as research at the point of sale allowed the verification of 24 companies.

In this sense, it is suggested in future studies, expand the study with other organizations of the universe of organic products industries, as well as identify gaps in supply, ie products which are not offered and which the consumer misses. This line also can be developed research marketing opportunities and product diversification strategies.

\section{REFERENCES}

BEKIN, S. F. Conversandosobre Endomarketing. São Paulo: Makron Books, 1995.

BERLIN, L.LOCKERETZ, W; BELL, R. Purchasing foods produced on organic, small and local farms: a mixed method analysis of New England consumers. Renewable agriculture and food systems. Cambridge, v. 24, pp 267-276, Dec. 2009.

BERRY, L.L. Relationship Marketing. In: BERRY, L.L.; SHOSTACK, G.L.; UPAH, G.D. Emerging Perspectives on Services Marketing. Chicago, American Marketing Association, pp. 25-28, 1983.

BITNER, M.J.; BOOMS, B.H.; MOHR, L.A. Critical Service Encounters: The Employee's Viewpoint. Journal of Marketing. Vol. 58 pp. 95-106, 1994

BORDEN, N.H. The Concept of the Marketing Mix. Journal of Advertising Research. Vol. 4 June, pp.2-7, 1964.

BRODIE, Roderick J., COVIELLO, Nicole E, WINKLHOFER, Heidi.Contemporary Marketing Practices research program: a review of the first decade. The Journal of Business \& Industrial Marketing. Santa Barbara, Vol. 23, Iss. 2, p. 84-94, 2008.

BRUM, Analisa de Medeiros. Endomarketing de A a Z: Como alinhar o pensamento das pessoas à estratégia da empresa. São Paulo: Integrare, 2010. 
BUILDING, Brand Loyalty. marketers use both travel and merchandise to hold customers. Advertising Age - Premiums\& Incentives, Chicago, maio de 1998.

CAMELO,MarjonyBarros;VIDAL,MauriceliaBezerra.OEndomarketingapartirdaPerspectivadeAprend izadoeCrescimentodoBalancedScorecard.In:IVSimpósiodeGestãoeEstratégiaemNegócios,Seropé dica,RJ,Brasil,Setembrode2006.

CERQUEIRA NETO, E. P. Reengenharia do negócio. São Paulo: Pioneira, 1994.

COBRA, Marcos. Administração de marketing no brasil. $3^{\circ}$ ed. Rio de Janeiro:Campus, 2009.

DAROLT, M.. Agricultura Orgânica: Inventando o Futuro. Londrina: IAPAR, 2002.

DWYER, F. Robert; SCHURR, Paul H.; OH, Sejo. Developing buyer-seller relationships. In: Jornal of Marketing, v. 51, n. 2, April 1987.

EMBRAPA. Empresa Brasileira de Pesquisa Agropecuária. Disponível em: http://www21.sede. embrapa.br. Acessado em mar/2011

GONÇALVES, Cid Filho; GUERRA, Renata S.; MOURA, Alexandre. Mensuração de satisfação, qualidade, lealdade, valor e expectativa em instituições de ensino superior: um estudo do modelo através de equações estruturais. Anais: ENANPAD, 2003.

GRÖNROOS, Christian. Marketing, gerenciamento e serviços. 2a.ed. Rio de Janeiro: Campus, 2003.

GRONROOS, Christian. The Marketing Strategy Continuum: Towards a Marketing Concept for the 1990s. Management Decision. Vol. 29 No 1 pp. 7- 13, 1991.

GUMMESSON, E. Is relationship marketing operational?.23rd EMAC -Conference Maastricht, 1994.

GUMMESSON, Evert.MarketingdeRelacionamentototal.3.SãoPaulo:Bookman,2010.

HALAL, W.E. From hierarchy to enterprise: internal markets are the foundation for a knowledge economy". Internal Marketing: Directions for Management, Routledge, London, pp. 3-23, 2000.

HOOF., C. H. Y. A Era dos Produtos Orgânicos.2000. Disponível em: http://www.janssencilag.com. $\mathrm{br} / \mathrm{dicas} S a u d e / d i c a s \_s a u d e 3$. asp?area $=\& i t e m=\& d i c a=19$. Acessoem 12/10/2005.

JOHNSON, Kurt; LEGER, Mark. Loyalty marketing: keeping in contact with the right customers. Direct Marketing, Garden City, v. 62, n. 5, p. 36-42, set. 1999

KOTLER, P. Administração de Marketing: a edição do novo milênio. São Paulo: Prentice Hall, 2000.

KOTLER, Philip. Administração de Marketing. 9 ed. São Paulo: 1998.

KOTLER, Philip; ARMSTRONG, G. Princípios de marketing.7 ed. Rio de Janeiro: Prentice-Hall, 1998.

KOTLER, Philip; ARMSTRONG, Gary. Princípios de marketing.12. São Paulo: Pearson, 2007.

LAGES, Natalia de Sales; NETO, Alcivio Vargas. Mensurando a Consciência Ecológica do Consumidor: Um Estudo Realizado na Cidade de Porto Alegre. Anais ENANPAD, 2003.

LEVIT, T. A Imaginação de Marketing. 2. ed. São Paulo: Atlas, 1990

LEVIT, Theodore. After the Sale Is Over. Harvard Business Review. Boston, v.61, n.5, p. 87-93, Sep/Oct 1983.

LIMONGI-FRANÇA, Ana Cristina. Práticas de recursos humanos: conceitos ferramentas e procedimentos. São Paulo: Atlas, 2009.

MCCARTHY, E.J. Basic Marketing Homewood: Irwin 240. Michael John Harker and John Egan, 1960.

MCGARRY, E.D. Some Functions of Marketing Reconsidered. In: COX, R.; ALDERSON, W. Theory of Marketing Chicago: Irwin, 1950.

MCKENA, Regis. Marketing de Relacionamento: estratégias bem-sucedidas para a era do cliente. $9^{\mathrm{a}}$ ed. Rio de Janeiro: Campus, 1992.

McKENNA, R. Marketing de Relacionamento: estratégias bem-sucedida para a era do cliente. Traduzido por outras palavras Consultoria Lingüística e Serviços de Informática. Rio de Janeiro: Campus, 1996.

NEVES et al, Marco Fava. Uma Proposta para Construção de Métodos de Planejamento e Gestão (Seqüência de Passos) nos Agronegócios. In: XXXII Encontro da ANPAD, 2008.

OLBRZYMEK, Juliana Regiani; OLBRZYMEK, Marilda Regiani; BRETZKE, Renato Osvaldo. Marketing de Relacionamento: grandes projetos não envolvem somente tecnologia. In: AGATHOS: Revista Cientifica da ASSEVIM, ANO 1, EDIÇAO 001, Outubro, 2005. 
Relationship Marketing in the Industrial Sector for Organic Products: The Assumption of Loyalty Programs Customers and Endomarketing

O'MALlEY, L.; PATTERSON, M. Vanishing Point: The Mix Management Paradigm Re-Viewed. Journal of Marketing Management.Vol.14 pp 829 - 851, 1998.

RIBEIRO, Áurea; COBRA, Marcos.Marketing: Magia e Sedução. São Paulo: Cobra, 2000.

ROCHA et al, Thelma Valéria. O uso de programas de fidelidade como instrumento para retenção de clientes no mercado de telefonia móvel. Um estudo de caso. In Semead, 2006.

ROCHA, Thelma; VELOSO, André. A hora da recompensa. São Paulo: Cobra, 1999.

SEVERINO, A.J. Metodologia do Trabalho Científico. 19.ed. São Paulo: Cortez, 1993

SHETH, J. N.; PARVATIYAR, A. The evolution of relationship marketing. International Business Review, [S.1.], v. 4, n. 4, 1995, p. 471-481

SHETH, J. N.; PARVATIYAR, A. The evolution of relationship marketing.International Business Review, [S.1.], v. 4, n. 4, 1995, p. 471-481

SOUZA, A. A.; SANTOS, G. J. Endomarketing: considerações teóricas e práticas de uma estratégia de integração. In: ANPAD, Marketing, vol. 5. Canela, RS: setembro de 1992.

STONE, M.; WOODCOCK, N.; MACHTYNIGER, L. Marketing de Relacionamento com os clientes. São Paulo: Futura, 2001

TAKALA, T.; UUSITALO, O. Na alternative view of relationship marketing: a framework for ethical analysis. European Journal of Marketing.vol. 30.n ${ }^{\circ} .2,1996$

THOMAS, B. The Characteristics of a Marketing Relationship. Quarterly Review of Marketing, Vol. 2, 1976.

TOFOLI, Eduardo Teraoka; TOFOLI, Irso; SANTOS, André Ricardo Ponce dos. Estratégia do Marketing de Relacionamento em Empresa Orientada para o Mercado na Conquista de uma Maior Participação do Mercado, In: IV Simpósio de Gestão e Estratégia em Negócios, Seropédica, RJ, Brasil, Setembro de 2006.

VARGO, S. L.; LUSCH, R.F. Evolving to a New Dominant Logic for Marketing. Journal of Marketing, Vol. 68, pp. 1-17, 2004

VAVRA, Terry G.Marketing de Relacionamento: after marketing. São Paulo: Atlas, 1993

VELOUTSOU, C; SAREN, M.; TZOKAS, N. Relationship Marketing, what if...?. European Journal of Marketing, Vol. 36, no. 4, pp. 433-449, 2002.

WATERSCHOOT, W; VAN DEN, Bulte. The 4P Classification of the Marketing Mix Revisited, Journal of Marketing: Vol. 56, p.83-93, October, 1992.

WHITELEY, R. A empresa totalmente voltada para o cliente, Rio de Janeiro: Campus, 1996

YAMASHITA, Sandra Sayuri; GOUVÊA, Maria Aparecida. Impactos e Implicações da Internet sobre o Marketing de Relacionamento. In: Enanpad, 2004. 